\title{
Air pollution, UV irradiation and skin carcinogenesis: what we know, where we stand and what is likely to happen in the future?
}

\author{
Barbara Zegarska ${ }^{1}$, Katarzyna Pietkun ${ }^{1,2}$, Wojciech Zegarski ${ }^{3}$, Paulina Bolibok ${ }^{4}$, Marek Wiśniewski ${ }^{4}$, Katarzyna Roszek $^{5}$, \\ Joanna Czarnecka ${ }^{5}$, Maciej Nowacki ${ }^{3}$

\begin{abstract}
${ }^{1}$ Chair of Cosmetology and Aesthetic Dermatology, Ludwik Rydygier's Collegium Medicum in Bydgoszcz, Nicolaus Copernicus University in Torun, Poland

${ }^{2}$ Chair and Department of Rehabilitation, Ludwik Rydygier's Collegium Medicum in Bydgoszcz, Nicolaus Copernicus University in Torun, Poland

${ }^{3}$ Chair and Department of Surgical Oncology, Ludwik Rydygier's Collegium Medicum in Bydgoszcz, Nicolaus Copernicus University in Torun, Oncology Centre - Professor Franciszek Łukaszczyk Memorial Hospital in Bydgoszcz, Poland

${ }^{4}$ Physicochemistry of Carbon Materials Research Group, Faculty of Chemistry, Nicolaus Copernicus University, Torun, Poland ${ }^{5}$ Department of Biochemistry, Faculty of Biology and Environment Protection, Nicolaus Copernicus University, Torun, Poland
\end{abstract}

Adv Dermatol Allergol 2017; XXXIV (1): 6-14 DOI: https://doi.org/10.5114/ada.2017.65616

\begin{abstract}
The link between air pollution, UV irradiation and skin carcinogenesis has been demonstrated within a large number of epidemiological studies. Many have shown the detrimental effect that UV irradiation can have on human health as well as the long-term damage which can result from air pollution, the European ESCAPE project being a notable example. In total, at present around 2800 different chemical substances are systematically released into the air. This paper looks at the hazardous impact of air pollution and UV and discusses: 1) what we know; 2) where we stand; and 3) what is likely to happen in the future. Thereafter, we will argue that there is still insufficient evidence of how great direct air pollution and UV irradiation are as factors in the development of skin carcinogenesis. However, future prospects of progress are bright due to a number of encouraging diagnostic and preventive projects in progress at the moment.
\end{abstract}

Key words: air pollution, skin carcinogenesis, UV irradiation.

\section{Introduction}

The term carcinogenesis refers to the process by which tumors develop, including the different biological and pathological mechanisms which are conducive to it $[1,2]$. To date, even though several publications have paid significant attention to this problem, there are still many unanswered questions, which means that it continues to be an area which requires further understanding [3-5]. For instance, only a few studies have been able to precisely detail how particular chemical substances, such as carcinogens, have a direct influence on neoplasm formation [6]. Those described more fully include asbestos, a carcinogen which causes lung mesothelioma; inorganic arsenic, a carcinogenic metalloid which is toxic to the liver; Zinc chromate which has been linked to lung cancer; and zalcitabine, a nucleoside analog reverse transcriptase inhibitor (NARTI) which the International Agency for Research on Cancer (IARC) lists as being possibly carcinogenic to humans [7-12].

Besides chemical agents, radiation and temperature levels are also considered important to carcinogenesis, these physical factors working alongside chemical ones. Notable examples include: how meat cooked at high temperatures can activate 2-amino-1-methyl6-phenylimidazo[4,5-b] pyridine, a carcinogen associated with breast cancer; or the way in which air pollution combines with ultraviolet solar radiation to induce different types of cancer [13-15].

One area, though, which has been largely neglected and considered insignificant is the particular role that air pollution may play in cases of skin carcinogenesis [16, 17]. This, however, has changed in recent years as air pollu-

Address for correspondence: Katarzyna Pietkun MD, MSc, Chair of Cosmetology and Aesthetic Dermatology, Ludwik Rydygier's Collegium Medicum, Nicolaus Copernicus University, 15 Jagiellońska St, 85-067 Bydgoszcz, Poland, phone: +48 525853424 , e-mail: pietkasia@wp.pl

Received: 11.02.2016, accepted: 17.05.2016. 
Table 1. The specific apportionment of PM factors according to their size and physical and chemical properties. Based on Fierro - "Particulate Matter" $2000[23,24]$

\begin{tabular}{|c|c|c|c|c|c|}
\hline Classification & Symbol & Diameter & Major source & $\begin{array}{l}\text { Potential } \\
\text { lifetime of PM }\end{array}$ & $\begin{array}{l}\text { Potential travel } \\
\text { distance of PM }\end{array}$ \\
\hline Coarse particles & $\mathrm{PM}_{10}$ & $\begin{array}{l}\text { From } 2.5 \mu \mathrm{m} \\
\text { to } 10 \mu \mathrm{m}\end{array}$ & $\begin{array}{l}\text { Air pollutants originated from urban, industrial, } \\
\text { traffic and agricultural sources }\end{array}$ & $\begin{array}{l}\text { From minutes } \\
\text { to hours }\end{array}$ & $\begin{array}{l}\text { from }<1 \mathrm{~km} \\
\text { to } 10 \mathrm{~km}\end{array}$ \\
\hline Fine particles & $\mathrm{PM}_{2.5}$ & $\begin{array}{l}\text { Less than } \\
2.5 \mu \mathrm{m}\end{array}$ & $\begin{array}{c}\text { Air pollutants originated from long-range } \\
\text { transport geogenic soil particles, anthropogenic } \\
\text { emissions from steel factories, road traffic } \\
\text { and industry emissions }\end{array}$ & $\begin{array}{l}\text { From days } \\
\text { to weeks }\end{array}$ & $\begin{array}{c}\text { From } 100 \mathrm{~km} \\
\text { to more than } \\
1000 \mathrm{~km}\end{array}$ \\
\hline
\end{tabular}

tion's impact on human health has been discussed more often, resulting in a number of studies, such as the European project ESCAPE, designed to investigate its longterm effects $[18,19]$. Findings of such research, including cohort and randomized trials, have shown that the skin is a target organ for pollution and allows exogenous agents to penetrate the body, resulting in oxidative damage to DNA $[17,20]$. In this paper we seek to present a compressive analysis of how air pollution and UV irradiation can result in skin carcinogenesis.

\section{What we know}

\section{Particulate matter}

Around 2800 different chemical substances are currently being systematically released into the air [21]. The most harmful of these are contained within particulate matter (PM) [22] which ranges in the diameter from around $\leq 2.5 \mu \mathrm{m}\left(\mathrm{PM}_{2.5}\right)$ to $10 \mu \mathrm{m}\left(\mathrm{PM}_{10}\right)$, the WHO considering $\mathrm{PM}_{2.5}$ to be the most hazardous, particularly to the lungs. More detailed information on the varying sizes of different PM can be found in Table 1 [23, 24], being associated with adverse health effects such as: heart disease and a higher cardiac risk; childbirth complications related to birth weight (BW) and preterm birth (PTB); and intensive pulmonary problems such as asthma, chronic obstructive pulmonary disease, lung cancer, and various respiratory infections [25-29]. Looking specifically at $\mathrm{PM}_{2.5}$, it has mainly been observed as inducing systemic inflammation, oxidative stress and pathological effects within C-reactive protein, white blood cells, fibrinogen and many other complexes, promoting carcinogenesis [29-31]. Its various components are mostly emitted daily in urban and industrial regions [32, 33], Table 2 detailing the five major soluble and insoluble variants [34-36].

Delving deeper into the existing literature, several reports exist which detail the negative pathological effect PM has on the skin, focusing mainly on how it accelerates the aging process which manifests itself in pigment spots and wrinkles [37]. At the same time, there are also a significant number of papers which indicate a direct link between PM and skin carcinogenesis [38], polycyclic aromatic hydrocarbons (PAHs) shown to promote bioactivation and tumor initiation. This is the case in several in vitro and in vivo studies which use human cell lines and laboratory mouse models whereby urban PM plays a key role in the inhibition of both cytochrome P450 1A1 and 1B1 (CYP1A1 and CYP1B1) and transcriptional repression (TIPARP), allowing for the occurrence of toxic and carcinogenic processes $[39,40]$. Another important research finding has centered on the role that $\mathrm{PM}_{10}$ plays in the development of skin cancer, having a delayed effect which means that clinical diagnoses are often made 7 to 14 years after the initial exposure to such substances [41].

\section{Polycyclic aromatic hydrocarbons as skin carcinogens}

Polycyclic aromatic hydrocarbons are a notable mixture of different aromatic compounds which are considered environmental pollutants, formed by the incomplete combustion of materials such as coal, tobacco, diesel, asphalt, creosote, gasoline, wood smoke, oil and $\operatorname{tar}$ [42]. So clear is the role of PAHs in skin carcinogenesis that mouse models are presently used to evaluate their individual potency, benign papillomas and malignant carcinomas being commonly attributed to them $[43,44]$. Indeed, there is a large volume of work which details the large extent to which PAHs have a direct effect on the skin. For instance, Lewis et al. and Modi et al. have shown in basic and pre-clinical studies that Langerhans cells (LCS) exposed extensively to PAHs facilitate epithelial DNA damage as a result of mutation among dendritic cells adjacent to basal, suprabasal and follicular infundibular keratinocytes, potentially leading to squamous cell carcinoma (SCC) [45-47]. Polycyclic aromatic hydrocarbons may also be responsible for the incidence of other non-melanoma skin cancers (NMSC), though

Table 2. The five major soluble and insoluble components of $\mathrm{PM}_{2.5}$ [34-36]

\begin{tabular}{lc}
\hline Soluble components & Insoluble components \\
\cline { 1 - 1 } Sulfate $\left(\mathrm{SO}_{4}{ }^{2-}\right)$ & Organic carbon (OC) \\
\cline { 1 - 1 } Nitrate $\left(\mathrm{NO}_{3}^{-}\right)$ & \\
\hline Ammonium $\left(\mathrm{NH}_{4}{ }^{+}\right)$ & Elemental carbon (EC) \\
\hline
\end{tabular}




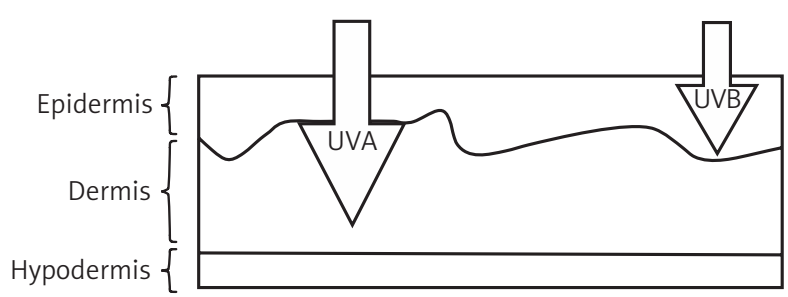

Figure 1. UVA and UVB penetration into the layers of the skin (based on $[65,67,73])$. Both UVA and UVB rays contribute to skin damage $[60,69,73]$ and although the mutagenic nature of UVB is much greater than that of UVA, the latter should not be underestimated $[65,67,75]$

samples drawing such conclusions are limited in scope to refinery, asphalt and other industrial workers [48, 49].

\section{Air pollution and UV irradiation}

To properly discuss the relationship between air pollution, UV irradiation and skin carcinogenesis, it is first important to outline the functions of the human skin as well as details about its structure. Its main role is to protect the body against the harmful effects of the surrounding environment [50] whilst preventing the excessive loss of various substances [51]. Paradoxically, it serves to connect the human organism with its surrounding environment [52] whilst providing a barrier against its negative effects, be they physical, chemical or mechanical [53]. When encountering UV radiation, the risk of cancer in the skin is greatly increased [54-59] and it is this interaction which makes it one of the most frequently diagnosed forms of cancer [60, 61].

Therefore, one of the best preventative measures is to limit the exposure of the skin to UV rays [61]. That is why it is so important to preserve the integrity of the epidermis which is no easy task [62]. For the simplest daily activities, even wearing clothes, make the stratum corneum exfoliate, meaning that new cells form to replace them as keratinocyte stem cells from the stratum basale undergo continuous proliferation $[63,64]$. These new cells migrate to the stratum corneum $[50,64]$ where they build a so-called "bricks and mortar" structure. Here, the composition of skin lipids differs greatly from the lipid composition of cell membranes within living cells [51], the stratum corneum containing a high volume of ceramides, cholesterol and free fatty acids among other lipids. Their quantity and kind subsequently influences the strength and integrity of the semipermeable barrier [50].

\section{Solar radiation}

The sun is a source of light and heat which supports the metabolic processes of different organisms $[65,66]$. It has a continuous spectrum and, at various wavelengths, consists of ultraviolet (UV), visible and infrared radiation $[54,66]$. Of all these, UV radia- tion has the most detrimental effect on human health [67]. Depending on the source, this can be defined as radiation of 100-400 $\mathrm{nm}$ [55, 67-69] or 200-400 $\mathrm{nm}[54,60,65,66]$ and is usually divided into three main ranges: UVA (400-324 nm), UVB (320-280 nm), and UVC $(<280 \mathrm{~nm})[55,68,70]$. Of that which reaches the Earth's surface, UVA radiation is the most prevalent (90-99\%), accompanied by a small amount of UVB radiation $(1-10 \%)[60,68,71]$, which is largely absorbed by the ozone layer along with UVC radiation [52, 54, 55]. In terms of the total amount of UV radiation which reaches the Earth's surface, this is dependent on the season, the time of a day, its latitude [52] and many other factors such as cloud cover or how thick the ozone layer is [72].

\section{The impact of UV radiation on the skin}

It continues to be difficult to describe how exactly different aspects of UV radiation affect the skin. The literature mostly refers to it without making a distinction between UVA and UVB radiation [55]. Meanwhile, studies which do have produced varying and inconsistent results, some concluding that UVB radiation is more mutagenic and cytotoxic to skin tissue $[59,69]$. These argue that this only penetrates the epidermis whilst long-wave UVA radiation reaches the dermis layer (Figure 1) [65, 67, 73]. However, others claim that UVB radiation penetrates the epidermis in addition to part of the dermis and that UVA radiation extends to subcutaneous tissue [66].

\section{UVA radiation}

This radiation causes oxidative damage, penetrating deeply into the skin whilst also being able to interact with keratinocytes, melanocytes and fibroblasts [74]. The cytotoxic effect of UVA exposure is significantly less than that of UVB radiation due to the fact that DNA is not a chromophore for UVA [75], and its genotoxic effects occur via an indirect mechanism. It can, nonetheless, induce oxidative stress in keratinocytes and other cells through the formation of reactive oxygen species (ROS) when the skin is exposed to it $[74,76]$. A result of this is irreparable damage to keratinocyte stem cells which is then transferred to "daughter cells" [64]. Moreover, many have suggested that skin exposure to this radiation at a range of 320-400 $\mathrm{nm}$ increases the risk of both melanoma and non-melanoma skin cancers $[58,67,74,77]$. Others, though, argue that although UVA rays penetrate far deeper into the human skin than UVB ones, it has a weak carcinogenic effect and only primarily results in aging of the skin [78].

\section{UVB radiation}

It has been shown that radiation of $280-320 \mathrm{~nm}$ is the most damaging to cells [78]. This is because DNA, containing aromatic rings, is a UVB-absorbing chromophore which results in photoproducts such as 6,4-pyrimi- 
done photoproduct (6,4-PP) and cyclobutane pyrimidine dimers (CPDs) such as T-C being generated [71, 79]. From this, the process of cancerogenesis in non-melanoma skin cancers can be triggered [78], in vitro and in vivo studies suggesting it can also contribute significantly to the development of melanoma [74]. In addition to this, and similarly to UVA rays, exposure to UVB radiation can generate reactive oxygen species which can damage DNA molecules and proteins, as well as lipids [68, 77, 78, 80]. Indeed, there is a lot of evidence that creates oxidative stress which results in inflammation of the epidermis and ultimately the pathogenesis of skin cancer [78, 80]. However, it should be added that ROS form at a much lower rate due to UVB rays than in the case of UVA radiation $[74,78]$.

\section{Reactive oxygen species}

Reactive oxygen species (ROS) are usually generated in the cell mitochondria during normal oxidative metabolism [76]. Maintaining the appropriate ROS concentration is necessary for normal functioning such as destroying microorganisms [81]. However, excessive levels of ROS can disrupt the equilibrium between its levels and those of antioxidant defense, resulting in oxidative stress [76, 81]. Looking at ROS in more detail alone, they can be divided into two main groups: oxygen molecules with unpaired electrons or oxygen molecules in excited states [82]. The first group includes superoxide anion radicals $\left(\mathrm{O}_{2}{ }^{--}\right)$, hydroxyl radicals $\left(\mathrm{OH}^{*}\right)$, and lipid peroxide $(\mathrm{LOO} \cdot)$ while the second group contains singlet oxygen $\left(\mathrm{O}_{2}\right)$ [82]. Among the most significant reactive oxygen species is hydrogen peroxide which plays a role in the development of many diseases as well as in the appearance of wrinkles and photo-aging of the skin [75]. Fundamentally then, ROS and free radicals play an important role in the formation of lipid radicals, leading to cell membrane damage [71, 83]. To prevent the formation of oxidative stress, nature has equipped the human body with a number of compounds such as enzymes which enable antioxidant action. One worth mentioning, at this stage, is superoxide dismutase which, along with anion superoxide, produces hydrogen peroxide which is usually neutralized by catalase [76]. However, excessive exposure of skin cells to UV radiation causes the immediate release of iron ions which can catalyze the production of toxic hydroxyl radicals due to the Fenton reaction, these being the main ROS responsible for the formation of lipid radicals more generally $[76,77]$.

\section{The body's defense against UV radiation and ROS}

In order to prevent oxidative stress and maintain redox equilibria, the human body is equipped with a network of antioxidant systems which are often classified as enzymatic or non-enzymatic ones [84]. The first group includes enzymes such as glutathione peroxidase (GPx), glutathione reductase, superoxide dismutase (SOD), and catalase (CAT) $[68,84]$, being activated as a result of excessive ROS emission. Meanwhile, the second group consists of small molecular antioxidants [78] including ascorbic acid, $\alpha$-tocopherol, uric acid and glutathione [84]. All in all, their task is to mitigate the adverse effects of UV radiation [78]. However, it is melanin, above all, which provides basic protection for the skin against its harmful effects, providing effective photoprotection by scattering radiation as a result of its pigment granules having a high refractive index relative to surrounding skin tissue $[74,85]$.

\section{Is UV radiation purely harmful?}

Ultraviolet radiation may also have a positive impact on the human skin [86] due to the fact that it causes the release of nitric oxide (NO) which has been suggested to lower blood pressure as well as having a positive effect on the cardiovascular system [86]. In addition, NO has the ability to protect against lipid peroxidation created as a result of exposure of the skin to UVB radiation [87]. Moreover, exposure of the skin to these rays is also said to enhance vitamin $\mathrm{D}_{3}$ synthesis, 7-dehydroksycholesterol absorbing UV light most effectively at wavelengths between 290 and $320 \mathrm{~nm}$ and enabling its conversion to pre-vitamin $D$ which isomerizes thermally into vitamin $D_{3}[57,63]$.

\section{Where we stand}

From a dermatological point of view, air pollution can be linked to a lengthy list of pathological skin manifestations and disorders. This includes different allergic reactions, rashes, eczema, acne and the more rapid aging of the skin through a loss of moisture and elasticity [88-92]. The British surgeon, Percivall Pott was the first to describe a potential link between pollution and carcinogenesis, noting the scrotal squamous carcinomas in British chimney sweeps and directly attributing them to their continuous exposure to carcinogens $[93,94]$. Nonetheless, it is problematic to assert that any freshly diagnosed skin lesion or recognized dermatosis is specifically due to air pollution. Doing so requires a demographical or local assessment of environmental impact $[95,96]$, which means that such etiology is easier corresponded to when the patient in question is from an area which is wellknown for its pollution such as a large urban agglomeration where smog occurs or a recognized industrial and mining region [97-99]. This, subsequently, can result in medical omissions, errors and cases of wrong diagnosis $[100,101]$. That is not to say that such methods are not useful with advances made related to clinical guidelines and recommendations continuing to enable the diagnosis and treatment of most malignant melanomas [102, 103]. At the same time, though, there is a lack of adequate resources to enable proper diagnostic tracks and 
Table 3. Characteristics of the most popular physical and chemical UV protection filters [107-110]

\begin{tabular}{lcc}
\hline $\begin{array}{l}\text { Type of UV filter used to protect } \\
\text { the skin }\end{array}$ & Main substrates used in production & $\begin{array}{c}\text { Spectrum of protection and time } \\
\text { to take effect }\end{array}$ \\
\hline Physical filters & $\begin{array}{c}\text { Titanium dioxide }\left(\mathrm{TiO}_{2}\right) \\
\text { Zinc oxide }(\mathrm{ZnO})\end{array}$ & $\begin{array}{c}\text { Stronger UVB protection than UVA, characterized } \\
\text { by fast action just after topical application }\end{array}$ \\
\hline Chemical filters & $\begin{array}{c}\text { Sulisobenzone, oxybenzone, octyl dimethyl } \\
\text { PABA, octyl methoxycinnamate, octyl } \\
\text { salicylate, homosalate, helioplex, 4-MBC }\end{array}$ & $\begin{array}{c}\text { Full protection and coverage against UVA } \\
\text { and UVB approximately 15-25 min after } \\
\text { application }\end{array}$ \\
\hline
\end{tabular}

Table 4. List of antioxidants for prevention of skin cancer and their major natural sources [117-122]

\begin{tabular}{lc}
\hline $\begin{array}{l}\text { Antioxidants for skin cancer } \\
\text { prevention }\end{array}$ & Major natural source \\
\hline Vitamin C (ascorbic acid) & $\begin{array}{c}\text { Blueberries, strawberries, } \\
\text { grapes, plums, prunes, red } \\
\text { beans, spinach, kale, broccoli }\end{array}$ \\
\hline$\beta$-Carotene & $\begin{array}{c}\text { Previously processed: carrots, } \\
\text { spinach and sweet potato }\end{array}$ \\
\hline Vitamin A (retinoic acid) & $\begin{array}{c}\text { Fish oil, pork and beef liver, } \\
\text { pumpkin }\end{array}$ \\
\hline Coenzyme Q10 & $\begin{array}{c}\text { Oily fish (salmon and tuna), } \\
\text { whole grains }\end{array}$ \\
\hline Glutathione & $\begin{array}{c}\text { Onion, potatoes, bananas, } \\
\text { apples }\end{array}$ \\
\hline Tea & Mostly in green tea \\
\hline Vitamin E $(\gamma$-tocopherol) & Canola oil, almonds, hazelnuts \\
\hline
\end{tabular}

screening, explaining why the current trend is to analyze epidemiological and environmental data together with national cancer reports and registries in each geographical region [104-106].

\section{How can we fight against air pollution} and the harmful effects of UV radiation?

Current strategies are largely based on prevention, mainly emerging from dermatology and cosmetology [107-109]. For instance, there are several products using physical and chemical filters to protect the skin [110, 111], photostable sunscreens being a perfect example along with other examples outlined in Table 3 [112]. Other widely used preventive measures include programs in tended to educate and raise awareness about the risks of exposing skin tissue to the sun and what can be done to mitigate them [111-113]. Such information has been considered especially helpful to cancer survivors, particularly those who have suffered from malignant melanoma, and young adolescents $[114,115]$. Related to this, has been the promotion of antioxidants as part of a healthy diet, their role as inhibitors being proved in a number of different pre-clinical and clinical studies. For example, it has been suggested that consuming food rich in antioxidants significantly enhances the natural biological production of melanin and other enzymatic antioxidants which help against UV radiation, examples along with their sources being listed in Table 4 [116-122]. Another initiative has involved the screening of people and groups at a higher risk of developing skin cancer such as those working in industry, though there is scope for improvement with indicators suggesting such programs have been limited in effect [123-131]. Perhaps this issue could be resolved by a more detailed study of existing skin cancer incidence reports and by focusing more on the role air pollution and UV irradiation may have played [132, 133].

\section{What is likely to happen in the future?}

Current literature indicates that there are broadly two paths of development. One is related to either building on the existing strategies or finding new ones, while the other focuses on the development and production of novel protective products such as sunscreens and dermocosmetics with an SPF filter $[41,134,135]$. One useful starting point, according to Fabbrocini et al., in building new strategies would be to try and foster greater general awareness of causative factors [136]. This is something the "European Code against Cancer $4^{\text {th }}$ Edition: Environment, occupation and cancer" by Espina et al. looks to do, suggesting the use of legislative tools to further spread information about how individuals can protect themselves and the role pollution can have in carcinogenesis [137]. Likewise, at the $23^{\text {rd }}$ World Congress of Dermatology in 2015, Dominique Moyal suggested the promotion of topical products which do not load the skin surface with particles, rinse-off products and high-quality sunscreens [138]. Elsewhere, more novel solutions include the further development and production of innovative protective products such as sunscreens and dermocosmetics which incorporate nanoparticles and nanosystems such as liposomes, nanoparticles, cyclodextrins and nanoemulsions. These could revolutionize cancer-prevention strategies and would rely on bioorganic materials including popular chitosan, lignosulfonate and others. However, as of yet, such solutions have only gone as far as the testing phase in both basic and pre-clinical studies, meaning there is still much work to be done [139-141].

\section{Conclusions}

Scientific understanding of the relationship between air pollution and skin carcinogenesis is something which 
continues to grow. This is in addition to greater knowledge about the role ultraviolet irradiation plays within this, facilitating pathological changes as it interacts with the many airborne chemicals and toxic particles inhaled daily by billions of people living around the world. Additionally, while there are around 2800 different chemical substances emitted systematically into the air, our focus can be narrowed down to two chemical groups. These are namely particulate matter and polycyclic aromatic hydrocarbons, both of which should be assessed together with physical factors such as UV irradiation whereby they play a seemingly synergistic role in carcinogenesis. In this paper, alongside ways in which air pollution impacts upon skin cancer, we have also discussed a number of preventative measures currently used and, to a lesser extent, the role of screening. This is in addition to looking at what is likely to happen in the future whereby the large volume of unknowns about the role of air pollution in skin carcinogenesis will be subject to further scrutiny not only in dermatology, but also in medicine more generally.

\section{Conflict of interest}

The authors declare no conflict of interest.

\section{References}

1. Yager JD, Davidson NE. Estrogen carcinogenesis in breast cancer. N Engl J Med 2006; 354: 270-82.

2. Nowacki M, Wisniewski M, Werengowska-Ciecwierz K, et al. Nanovehicles as a novel target strategy for hyperthermic intraperitoneal chemotherapy: a multidisciplinary study of peritoneal carcinomatosis. Oncotarget 2015; 6: 22776-98.

3. Emiroglu N, Pelin Cengiz F, Hofmann-Wellenhof R. Dermoscopic and clinical features of trunk melanomas. Postep Dermatol Alergol 2014; 31: 362-7.

4. Nowacki M, Wiśniewski M, Werengowska-Ciećwierz K, et al. New application of carbon nanotubes in haemostatic dressing filled with anticancer substance. Biomed Pharmacother 2015; 69: 349-54.

5. Skowronek J. Brachytherapy in the treatment of skin cancer: an overview. Postep Dermatol Alergol 2015; 32: 362-7.

6. Hecht SS. Tobacco smoke carcinogens and lung cancer. J Natl Cancer Inst 1999; 91: 1194-210.

7. Zhang W, WuX, Wu L, et al. Advances in the diagnosis, treatment and prognosis of malignant pleural mesothelioma. Ann Transl Med 2015; 3: 182.

8. Peng WJ, Mi J, Jiang YH. Asbestos exposure and laryngeal cancer mortality. Laryngoscope 2016; 126: 1169-74.

9. Uccello M, Malaguarnera G, Corriere T, et al. Risk of hepatocellular carcinoma in workers exposed to chemicals. Hepat Mon 2012; 12: e5943.

10. Liu J, Waalkes MP. Liver is a target of arsenic carcinogenesis. Toxicol Sci 2008; 105: 24-32.

11. Davies JM. Lung cancer mortality among workers making lead chromate and zinc chromate pigments at three English factories. Br J Ind Med 1984; 41: 158-69.

12. Brambilla G, Mattioli F, Robbiano L, Martelli A. Studies on genotoxicity and carcinogenicity of antibacterial, antiviral, antimalarial and antifungal drugs. Mutagenesis 2012; 27: 387-413.
13. Sinha R, Gustafson DR, Kulldorff M, et al. 2-amino-1-methyl-6-phenylimidazo[4,5-b]pyridine, a carcinogen in hightemperature-cooked meat, and breast cancer risk. I Natl Cancer Inst 2000; 92: 1352-4.

14. Varotsos A, Chronopoulos GJ, Katsikis S, Sakellariou NK. Further evidence of the role of air pollution on solar ultraviolet radiation reaching the ground. Int I Remote Sens 1995; 16: 1883-6.

15. D'Agostini F, Balansky R, Steele VE, et al. Preneoplastic and neoplastic lesions in the lung, liver and urinary tract of mice exposed to environmental cigarette smoke and UV light since birth. Int J Cancer 2008; 123: 2497-502.

16. Truong H, Lomnicki S, Dellinger B. Potential for misidentification of environmentally persistent free radicals as molecular pollutants in particulate matter. Environ Sci Technol 2010; 44: 1933-9.

17. Vineis P, Husgafvel-Pursiainen K. Air pollution and cancer: biomarker studies in human populations. Carcinogenesis 2005; 26: 1846-55.

18. Guxens M, Ghassabian A, Gong T, et al. Air pollution exposure during pregnancy and childhood autistic traits in four European population-based cohort studies: the ESCAPE Project. Environ Health Perspect 2016; 2016: 133-40.

19. Lanki T, Hampel R, Tiittanen P, et al. Air pollution from road traffic and systemic inflammation in adults: a crosssectional analysis in the European ESCAPE Project. Environ Health Perspect 2015; 123: 785-91.

20. Goldsmith LA. Skin effects of air pollution. Otolaryngol Head Neck Surg 1996; 114: 217-9.

21. Lewtas J. Airborne carcinogens. Pharmacol Toxicol 1993; 72: 55-63.

22. Sgrigna G, Baldacchini C, Esposito R, et al. Characterization of leaf-level particulate matter for an industrial city using electron microscopy and X-ray microanalysis. Sci Total Environ 2016; 548-549: 91-9.

23. Fierro M. Particulate matter. Air Info Now 2000; 1-11.

24. Yu Y, Schleicher N, Norra S, et al. Dynamics and origin of $\mathrm{PM}_{25}$ during a three-year sampling period in Beijing, China. J Environ Monit 2011; 13: 334-46.

25. Sullivan J, Ishikawa N, Sheppard L, et al. Exposure to ambient fine particulate matter and primary cardiac arrest among persons with and without clinically recognized heart disease. Am J Epidemiol 2003; 157: 501-9.

26. Lamichhane DK, Leem JH, Lee JY, Kim HC. A meta-analysis of exposure to particulate matter and adverse birth outcomes. Environ Health Toxicol 2015; 30: e2015011.

27. Kurt OK, Zhang J, Pinkerton KE. Pulmonary health effects of air pollution. Curr Opin Pulm Med 2016; 22: 138-43.

28. Meo SA, Suraya F. Effect of environmental air pollution on cardiovascular diseases. Eur Rev Med Pharmacol Sci 2015; 19: 4890-7.

29. Dabass A, Talbott EO, Venkat A, et al. Association of exposure to particulate matter $\left(\mathrm{PM}_{2.5}\right)$ air pollution and biomarkers of cardiovascular disease risk in adult NHANES participants (2001-2008). Int J Hyg Environ Health 2015; S1438-4639: 00159-5.

30. Kim JY, Chen JC, Boyce PD, Christiani DC. Exposure to welding fumes is associated with acute systemic inflammatory responses. Occup Environ Med 2005; 62: 157-63.

31. Huttunen K, Siponen T, Salonen I, et al. Low-level exposure to ambient particulate matter is associated with systemic inflammation in ischemic heart disease patients. Environ Res 2012; 116: 44-51. 
32. Querol X, Alastuey A, Rodríguez S, et al. Levels of particulate matter in rural, urban and industrial sites in Spain. Sci Total Environ 2004; 334-335: 359-76.

33. Moreno T, Jones TP, Richards RJ. Characterisation of aerosol particulate matter from urban and industrial environments: examples from Cardiff and Port Talbot, South Wales, UK. Sci Total Environ 2004; 334-335: 337-46.

34. Aneja VP, Wang B, Tong DQ, et al. Characterization of major chemical components of fine particulate matter in North Carolina. J Air Waste Manag Assoc 2006; 56: 1099-107.

35. Manousakas M, Papaefthymiou H, Eleftheriadis K, Katsanou K. Determination of water-soluble and insoluble elements in PM $_{2.5}$ by ICP-MS. Sci Total Environ 2014; 493: 694-700.

36. Verma V, Rico-Martinez R, Kotra N, et al. Contribution of water-soluble and insoluble components and their hydrophobic/hydrophilic subfractions to the reactive oxygen species-generating potential of fine ambient aerosols. Environ Sci Technol 2012; 46: 11384-92.

37. Vierkötter A, Krutmann J. Environmental influences on skin aging and ethnic-specific manifestations. Dermatoendocrinol 2012; 4: 227-31.

38. Valavanidis A, Vlachogianni T, Fiotakis K, Loridas S. Pulmonary oxidative stress, inflammation and cancer: respirable particulate matter, fibrous dusts and ozone as major causes of lung carcinogenesis through reactive oxygen species mechanisms. Int J Environ Res Public Health 2013; 10: 3886-907.

39. Courter LA, Musafia-Jeknic T, Fischer K, et al. Urban dust particulate matter alters $\mathrm{PAH}$-induced carcinogenesis by inhibition of CYP1A1 and CYP1B1. Toxicol Sci 2007; 95: 63-73.

40. Líbalová H, Krčková S, Uhlírová K, et al. Genotoxicity but not the AhR-mediated activity of PAHs is inhibited by other components of complex mixtures of ambient air pollutants. Toxicol Lett 2014; 225: 350-7.

41. Yanagi Y, Assunção JV, Barrozo LV. The impact of atmospheric particulate matter on cancer incidence and mortality in the city of São Paulo, Brazil. Cad Saude Publica 2012; 28: 1737-48.

42. Siddens LK, Larkin A, Krueger SK, et al. Polycyclic aromatic hydrocarbons as skin carcinogens: comparison of benzo[a] pyrene, dibenzo[def,p]chrysene and three environmental mixtures in the FVB/N mouse. Toxicol Appl Pharmacol 2012; 264: 377-86.

43. Melendez-Colon VJ, Luch A, Seidel A, Baird WM. Cancer initiation by polycyclic aromatic hydrocarbons results from formation of stable DNA adducts rather than apurinic sites. Carcinogenesis 1999; 20: 1885-91.

44. Melendez-Colon VJ, Smith CA, Seidel A, et al. Formation of stable adducts and absence of depurinating DNA adducts in cells and DNA treated with the potent carcinogen dibenzo[a,l]pyrene or its diol epoxides. Proc Natl Acad Sci USA 1997; 94: 13542-7.

45. Lewis JM, Bürgler CD, Fraser JA, et al. Mechanisms of chemical cooperative carcinogenesis by epidermal Langerhans cells. J Invest Dermatol 2015; 135: 1405-14.

46. Modi BG, Neustadter J, Binda E, et al. Langerhans cells facilitate epithelial DNA damage and squamous cell carcinoma. Science 2012; 335: 104-8.

47. Anderson C, Hehr A, Robbins R, et al. Metabolic requirements for induction of contact hypersensitivity to immunotoxic polyaromatic hydrocarbons. J Immunol 1995; 155: 3530-7.
48. Young C, Rushton L. British Occupational Cancer Burden Study Group. Occupational cancer in Britain. Skin cancer. Br J Cancer 2012; 107: S71-5.

49. Partanen T, Boffetta P. Cancer risk in asphalt workers and roofers: review and meta-analysis of epidemiologic studies. Am J Ind Med 1994; 26: 721-40.

50. Nicolaoua A, Pilkingtonb SM, Rhodesb LE. Ultraviolet-radiation induced skin inflammation: dissecting the role of bioactive lipids. Chem Phys Lipids 2011; 164: 535-43.

51. Bouwstra JA, Honeywell-Nguyen PL. Skin structure and mode of action of vesicles. Adv Drug Deliver Rev 2002; 54 : S41-55.

52. Young AR. Acute effects of UVR on human eyes and skin. Prog Biophys Mol Bio 2006; 92: 80-5.

53. Letizia Manca M, Marongiu F, Castangia I, et al. Protective effect of grape extract phospholipid vesicles against oxidative stress skin damages. Ind Crop Prod 2016; 83: 561-7.

54. Matsumura Y, Ananthaswamy HN. Toxic effects of ultraviolet radiation on the skin. Toxicol Appl Pharm 2004; 195: 298-308.

55. Gallaghera RP, Leea TK. Adverse effects of ultraviolet radiation: a brief review. Prog Biophys Mol Bio 2006; 92: 119-31.

56. Kimlin MG, Guo Y. Assessing the impacts of lifetime sun exposure on skin damage and skin aging using a non-invasive method. Sci Total Environ 2012; 425: 35-41.

57. Godar DE, Landry RJ, Lucas AD. Increased UVA exposures and decreased cutaneous vitamin D3 levels may be responsible for the increasing incidence of melanoma. Med Hypotheses 2009; 72: 434-43.

58. Greinert R, Boniol M. Skin cancer - primary and secondary prevention (information campaigns and screening) with a focus on children and sunbeds. Biophys Mol Bio 2011; 107: 473-6.

59. Ji C, Yang B, Yang Z, et al. Ultra-violet B (UVB)-induced skin cell death occurs through a cyclophilin D intrinsic signaling pathway. Biochem Bioph Res Com 2012; 425: 825-9.

60. Bachelor MA, Bowden GT. UVA-mediated activation of signaling pathways involved in skin tumor promotion and progression. Semin Cancer Biol 2004; 14: 131-8.

61. Daniel LC, Heckman CJ, Kloss JD, Manne SL. Comparing alternative methods of measuring skin color and damage. Cancer Causes Control 2009; 20: 313-21.

62. Nielsen JB. Percutaneous penetration through slightly damaged skin. Arch Dermatol Res 2005; 296: 560-7.

63. Masona RS, Sequeira VB, Dixon KM, et al. Photoprotection by 1alpha,25-dihydroxyvitamin D and analogs: further studies on mechanisms and implications for UV-damage. J Steroid Biochem 2010; 121: 164-8.

64. Ruetze M, Dunckelmann K, Schade A, et al. Damage at the root of cell renewal - UV sensitivity of human epidermal stem cells. J Derm Sci 2011; 64: 16-22.

65. Azevedo JS, Viana Jr NS, Vianna Soares CD. UVA:UVB sunscreen determination by second-order derivative ultraviolet spectrophotometry. II Farmaco 1999; 54: 573-8.

66. Goswami S, Haldar C. Melatonin as a possible antidote to UV radiation induced cutaneous damages and immune suppression: an overview. J Photoch Photobiol B 2015; 153: 281-8.

67. Schauena M, Hornig-Doa H, Schomberga S, et al. Mitochondrial electron transport chain activity is not involved in ultraviolet A (UVA)-induced cell death. Free Radical Biol Med 2007; 42: 499-509.

68. Salucci S, Burattini S, Curzi D, et al. Antioxidants in the prevention of UVB-induced keratynocyte apoptosis. J Photochem Photobiol B 2014; 141: 1-9. 
69. Svobodová A, Zdařilová A, Mališková J, et al. Attenuation of UVA-induced damage to human keratinocytes by silymarin. J Derm Sci 2007; 46: 21-30.

70. Krutmann J. Ultraviolet A radiation-induced biological effects in human skin: relevance for photoaging and photodermatosis. J Derm Sci 2000; 23: S22-6.

71. Herrling T, Jung K, Fuchs J. The role of melanin as protector against free radicals in skin and its role as free radical indicator in hair. Spectrochim Acta A 2008; 69: 1429-35.

72. Medhaug I, Olseth JA, Reuder J. UV radiation and skin cancer in Norway. J Photochem Photobiol B 2009; 96: 232-41.

73. Jeong YM, Ha JH, Park SN. Cytoprotective effects against UVA and physical properties of luteolin-loaded cationic solid lipid nanoparticle. J Ind Eng Chem 2016; 35: 54-62.

74. Swalwell H, Latimer J, Haywood RM, Birch-Machin MA. Investigating the role of melanin in UVA/UVB- and hydrogen peroxide-induced cellular and mitochondrial ROS production and mitochondrial DNA damage in human melanoma cells. Free Radical Biol Med 2012; 52: 626-34.

75. Ichihashi M, Ueda M, Budiyanto A, et al. UV-induced skin damage. Toxicology 2003; 189: 21-39.

76. Petersen AB, Gniadecki R, Vicanova J, et al. Hydrogen peroxide is responsible for UVA-induced DNA damage measured by alkaline comet assay in HaCaT keratinocytes. J Photoch Photobiol B 2000; 59: 123-31.

77. Baier J, Maisch T, Maier M, et al. Direct detection of singlet oxygen generated by UVA irradiation in human cells and skin. J Invest Dermatol 2007; 127: 1498-506.

78. Filip A, Daicoviciu D, Clichici S, et al. The effects of grape seeds polyphenols on SKH-1 mice skin irradiated with multiple doses of UV-B. J Photochem Photobiol B 2011; 105: 133-42.

79. Divya SP, Wang X, Pratheeshkumar P, et al. Blackberry extract inhibits UVB-induced oxidative damage and inflammation through MAP kinases and NF-kappaB signaling pathways in SKH-1 mice skin. Toxicol Appl Pharm 2015; 284: 92-9.

80. Choi K, Kundu JK, Chun K, et al. Rutin inhibits UVB radiation-induced expression of COX-2 and iNOS in hairless mouse skin: p38 MAP kinase and JNK as potential targets. Arch Biochem Biophys 2014; 559: 38-45.

81. Penga Y, Xuanb M, Leunga VYL, Cheng B. Stem cells and aberrant signaling of molecular systems in skin aging. Ageing Res Rev 2015; 19: 8-21.

82. Masaki $H$. Role of antioxidants in the skin: anti-aging effects. J Dermatol Sci 2010; 58: 85-90.

83. Herrling Th, Jung K, Fuchs J. Measurements of UV-generated free radicals/reactive oxygen species (ROS) in skin. Spectrochim Acta A 2006; 63: 840-5.

84. Peres PS, Terra VA, Guarnier FA, et al. Photoaging and chronological aging profile: understanding oxidation of the skin. J Photochem Photobiol B 2011; 103: 93-7.

85. Nielsen KP, Zhao L, Stamnes JJ, et al. The importance of the depth distribution of melanin in skin for DNA protection and other photobiological processes. J Photochem Photobiol B 2006; 82: 194-8.

86. Halliday GM, Byrne SN. An unexpected role: UVA-induced release of nitric oxide from skin may have unexpected health benefits. J Invest Dermatol 2014; 134: 1791-4.

87. Terra VA, Souza-Neto FP, Pereira RC, et al. Time-dependent reactive species formation and oxidative stress damage in the skin after UVB irradiation. J Photochem Photobiol B 2012; 109: 34-41.

88. Vimercati L, Gatti MF, Baldassarre A, et al. Occupational exposure to urban air pollution and allergic diseases. Int J Environ Res Public Health 2015; 12: 12977-87.
89. Wang IJ, Tung TH, Tang CS, Zhao ZH. Allergens, air pollutants, and childhood allergic diseases. Int J Hyg Environ Health 2016; 219: 66-71.

90. Mancebo SE, Wang SQ. Recognizing the impact of ambient air pollution on skin health. J Eur Acad Dermatol Venereol 2015; 29: 2326-32.

91. Li M, Vierkötter A, Schikowski T, et al. Epidemiological evidence that indoor air pollution from cooking with solid fuels accelerates skin aging in Chinese women. J Dermatol Sci 2015; 79: 148-54.

92. Tavacol H, Rahimi Z, Cheraghi M, et al. A cross-sectional study of prevalence and risk factors for childhood asthma in Ahvaz city, Iran. Postep Dermatol Alergol 2015; 32: 268-73.

93. Weyers W. Confusion-specimen mix-up in dermatopathology and measures to prevent and detect it. Dermatol Pract Concept 2014; 4: 27-42.

94. English JS, Dawe RS, Ferguson J. Environmental effects and skin disease. Br Med Bull 2003; 68: 129-42.

95. Kousha T, Valacchi G. The air quality health index and emergency department visits for urticaria in Windsor, Canada. J Toxicol Environ Health A 2015; 78: 524-33.

96. Song Y, Hou J, Huang X, et al. The Wuhan-Zhuhai (WHZH) cohort study of environmental air particulate matter and the pathogenesis of cardiopulmonary diseases: study design, methods and baseline characteristics of the cohort. BMC Public Health 2014; 14: 994.

97. Behrendt H, Alessandrini F, Buters J, et al. Environmenta pollution and allergy: historical aspects. Chem Immunol Allergy 2014; 100: 268-77.

98. Rutkowski K, Sowa P, Rutkowska-Talipska J, et al. Allergic diseases: the price of civilisational progress. Postep Dermatol Alergol 2014; 31: 77-83.

99. Street TD, Thomas DL. Employee factors associated with interest in improving sun protection in an Australian mining workforce. Health Promot J Austr 2015; 26: 33-8.

100. Bourne KM. Mine workers, heat related illnesses, and the role of the occupational health nurse. Ky Nurse 2015; 63: 6-7.

101. Kamińska-Winciorek G, Placek W. The most common mistakes on dermatoscopy of melanocytic lesions. Postep Dermatol Alergol 2015; 32: 33-9.

102. Kotwal S, Madaan S, Prescott S, et al. Unusual squamous cell carcinoma of the scrotum arising from a well healed, innocuous scar of an infertility procedure: a case report. Ann R Coll Surg Engl 2007; 89: W17-9.

103. Spuls PI, Nast A. Evaluation of and perspectives on guidelines: what is important? J Invest Dermatol 2010; 130: 2348-9.

104. Trotter SC, Sroa N, Winkelmann RR, et al. A global review of melanoma follow-up guidelines. J Clin Aesthet Dermatol 2013; 6: 18-26.

105. Ibrahim AS, Khaled HM, Mikhail NN, et al. Cancer incidence in Egypt: results of the national population-based cancer registry program. J Cancer Epidemiol 2014; 2014: 437971.

106. Pukkala E, Martinsen J, Lynge E, et al. Occupation and cancer - follow-up of 15 million people in five Nordic countries. Acta Oncol 2009; 48: 646-790.

107. Chisvert A, Pascual-Martí MC, Salvador A. Determination of the UV filters worldwide authorised in sunscreens by high-performance liquid chromatography. Use of cyclodextrins as mobile phase modifier. J Chromatogr A 2001; 921: 207-15.

108. Downs CA, Kramarsky-Winter E, Segal R, et al. Toxicopathological effects of the sunscreen UV filter, oxybenzone (benzophenone-3), on coral planulae and cultured primary cells and its environmental contamination in Hawaii and 
the U.S. virgin islands. Arch Environ Contam Toxicol 2016; 70: 265-88.

109. Rastogi SC. UV filters in sunscreen products - a survey. Contact Dermatitis 2002; 46: 348-51.

110. Rai R, Shanmuga SC, Srinivas C. Update on photoprotection. Indian J Dermatol 2012; 57: 335-42.

111. Pavicic T, Steckmeier S, Kerscher M, Korting HC. Evidencebased cosmetics: concepts and applications in photoaging of the skin and xerosis. Wien Klin Wochenschr 2009; 121: 431-9.

112. Koch S, Pettigrew S, Strickland M, et al. Sunscreen increasingly overshadows alternative sun-protection strategies. J Cancer Educ 2016; 10: 1-4.

113. Nahar VK, Allison Ford M, Brodell RT, et al. Skin cancer prevention practices among malignant melanoma survivors: a systematic review. J Cancer Res Clin Oncol 2016; 142: 1273-83.

114. Morabito K, Shapley NC, Steeley KG, Tripathi A. Review of sunscreen and the emergence of non-conventional absorbers and their applications in ultraviolet protection. Int J Cosmet Sci 2011; 33: 385-90.

115. Schroeder P, Krutmann J. What is needed for a sunscreen to provide complete protection. Skin Therapy Lett 2010; 15: 4-5.

116. Gaspar LR, Maia Campos PM. Evaluation of the photostability of different UV filter combinations in a sunscreen. Int J Pharm 2006; 307: 123-8.

117. Godic A, Poljšak B, Adamic M, Dahmane R. The role of antioxidants in skin cancer prevention and treatment. Oxid Med Cell Longev 2014; 2014: 860479.

118. Shebis Y, Iluz D, Kinel-Tahan Y, et al. Natural antioxidants: function and sources. Food Nutr Sci 2013; 4: 643-9.

119. Strobel M, Tinz J, Biesalski HK. The importance of betacarotene as a source of vitamin A with special regard to pregnant and breastfeeding women. Eur J Nutr 2007; 46 Suppl. 1: 11-20.

120. Rock CL, Lovalvo JL, Emenhiser C, et al. Bioavailability of beta-carotene is lower in raw than in processed carrots and spinach in women. J Nutr 1998; 128: 913-6.

121. Saini R. Coenzyme Q10: the essential nutrient. J Pharm Bioallied Sci 2011; 3: 466-7.

122. Edefonti V, Hashibe M, Parpinel M, et al. Vitamin E intake from natural sources and head and neck cancer risk: a pooled analysis in the International Head and Neck Cancer Epidemiology consortium. Br J Cancer 2015; 113: 182-92.

123. Fernández-Morano T, Rivas-Ruiz F,deTroya-Martín M, et al. Adolescents' attitudes to sun exposure and sun protection. J Cancer Educ 2016; 1: 1-8.

124. Heckman C, Darlow S, Munshi T, et al. Development of an internet intervention to address behaviors associated with skin cancer risk among young adults. Internet Interv 2015; 2: 340-50.

125. Sumen A, Oncel S. Effect of skin cancer training provided to Maritime High School students on their knowledge and behaviour. Asian Pac J Cancer Prev 2015; 16: 7769-79.

126. Nahar VK, Allison Ford M, Brodell RT, et al. Skin cancer prevention practices among malignant melanoma survivors: a systematic review. J Cancer Res Clin Oncol 2016; 142: 1273-83.

127. Heckman CJ, Darlow SD, Ritterband LM, et al. Efficacy of an intervention to alter skin cancer risk behaviors in young adults. Am J Prev Med 2016; S0749-3797: 00748-5.

128. Federman DG, Kravetz JD, Kirsner RS. Skin cancer screening by dermatologists: prevalence and barriers. J Am Acad Dermatol 2002; 46: 710-4.
129. Geller AC, O’Riordan DL, Oliveria SA, et al. Overcoming obstacles to skin cancer examinations and prevention counseling for high-risk patients: results of a national survey of primary care physicians. J Am Board Fam Pract 2004; 17: 416-23.

130. Schaefer I, Rustenbach SJ, Zimmer L, Augustin M. Prevalence of skin diseases in a cohort of 48,665 employees in Germany. Dermatology 2008; 217: 169-72.

131. Augustin M, Herberger K, Hintzen S, et al. Prevalence of skin lesions and need for treatment in a cohort of 90880 workers. Br J Dermatol 2011; 165: 865-73.

132. Araki K, Nagano T, Ueda M, et al. Incidence of skin cancers and precancerous lesions in Japanese: risk factors and prevention. J Epidemiol 1999; 9: S14-21.

133. Siesling S, van der Aa MA, Coebergh JW, Pukkala E. Working Group of The Netherlands Cancer Registry. Time-space trends in cancer incidence in the Netherlands in 19892003. Int J Cancer 2008; 122: 2106-14.

134. Ali I, Wani WA, Salee K. Cancer scenario in India with future perspectives. Cancer Therapy 2011; 8: 56-70.

135. Glanz K, Saraiya M, Wechsler H. Centers for disease control and prevention. Guidelines for school programs to prevent skin cancer. MMWR Recomm Rep 2002; 51: 1-18.

136. Fabbrocini G, Triassi M, Mauriello MC, et al. Epidemiology of skin cancer: role of some environmental factors. Cancers (Basel) 2010; 2: 1980-9.

137. Espina C, Straif K, Friis S, et al. European code against cancer $4^{\text {th }}$ edition: environment, occupation and cancer. Cancer Epidemiol 2015; 39 Suppl. 1: S84-92.

138. Moyal D. Strategies for prevention of pollution-induced skin disorders. "Skin damages related to pollution: a new challenge for dermatologists" Krutmann J, Moyal D (eds). La Roche-Posay materials issued during $23^{\text {rd }}$ World Congress of Dermatology, Vancouver 2015.

139. Coutinho Cdos S, Dos Santos EP, Mansur CR. Nanosystems in photoprotection. J Nanosci Nanotechnol 2015; 15: 9679-88.

140. Nguyen MH, Hwang IC, Park HJ. Enhanced photoprotection for photo-labile compounds using double-layer coated corn oil-nanoemulsions with chitosan and lignosulfonate. J Photochem Photobiol B 2013; 125: 194-201.

141. Nguyen HM, Hwang IC, Park JW, Park HJ. Photoprotection for deltamethrin using chitosan-coated beeswax solid lipid nanoparticles. Pest Manag Sci 2012; 68: 1062-8. 